\title{
Analisis kebutuhan pemustaka pada kegiatan layanan pengembangan koleksi buku Perpustakaan IAIN Batusangkar
}

\author{
Tri Yuliani \\ Dosen Ilmu Perpustakaan dan Informasi Islam IAIN Batusangkar \\ Email: triyuliani@iainbatusangkar.ac.id
}

\begin{abstract}
This study analyzes the needs of users' collections through the development of collections conducted by the Batusangkar IAIN library. This research is a case study conducted using the description method that illustrates the implementation and obstacles faced by the library, there is a collection development analysis activity according to user needs. the benchmarks in this research are study materials or strategies that will be applied for the future by improving the present situation. This study provides findings that activities and evaluations must be carried out on all planning processes with in-depth analysis of the needs of the visitors. This situation causes the librarians to be confused to develop a collection of books so that they cannot determine the type of collection that is needed by the user. More in-depth analysis activities by auditing information and interviews with users are needed for library development.
\end{abstract}

Keywords: Library, Collection Development, Needs Analysis

\begin{abstract}
ABSTRAK
Penelitian ini menganalisis kebutuhan koleksi pengguna melalui pengembangan koleksi yang dilakukan oleh Perpustakaan IAIN Batusangkar. Penelitian ini merupakan studi kasus yang dilakukan dengan menggunakan metode deskripsi yang menggambarkan pelaksanaan dan hambatan yang dihadapi oleh perpustakaan ada kegiatan analisis pengembangan koleksi sesuai kebutuhan pengguna. Tolak ukur dalam penelitian ini merupakan bahan kajian atau strategi yang akan diterapkan untuk masa mendatang dengan memperbaiki keadaan sekarang. Penelitian ini memberikan temuan bahwa harus dilakukan kegiatan dan evaluasi pada semua peroses perencanaan dengan analisis mendalam terhadap kebutuhan yang diinginkan pemustaka. Keadaan ini mengakibatkan pustakawan bingung untuk mengembangkan koleksi buku sehingga mereka tidak dapat menentukan jenis koleksi yang dibutuhkan pemustaa. Kegiatan analisis yang lebih mendalam dengan mengaudit informasi dan wawancara dengan pengguna sangat dibutuhkan untuk pengembangan perpustakaan.
\end{abstract}

Kata kunci: Perpustakaan, Pengembangan Koleksi, Analisis Kebutuhan

\section{A. PENDAHULUAN}

Koleksi perpustakaan adalah sarana informasi yang menjadi aktor utama dalam mendukung layanan perpustakaan serta merupakan gudang sumber informasi bagi pemustaka yang menggunakan koleksi perpustakaan. Koleksi perpustakaan terdiri dari buku-buku, majalah, jurnal dan publikasi lain yang dikumpulkan, diproses, dan disimpan oleh perpustakaan sehingga dapat ditemukan dan dipanggil kembali (temu balik) secara berulang-ulang bagi pengguna dalam menciptakan layanan untuk kebutuhan pemustaka yang lebih maksimal. Pengembangan koleksi merupakan rangkaian kegiatan penting di 
perpustakaan dengan menambahkan koleksi perpustakaan dan memaksimalkan koleksi sesuai dengan kebutuhan pemustaka (G. Edward Evans, 2005). Memastikan kebutuhan pengguna sesuai dan terpenuhi, maka kegiatan pengembangan koleksi perpustakaan dilakukan dengan analisis yang menyeluruh dimulai dari pengumpulan dara kebutuhanpengguna, analisis kebutuhan, pengelompokkan, dan melakukan pengadaan sesuai kebutuhan pengguna berdasarkan analisis yang telah dibuat.

Indonesia sebagai negara institusi yang melek huruf dan membutuhkan sumber informasi yang terbaru dan terkini secara instan, cepat, tepat dapat diwakili oleh organisasi penyedia informasi yaitu perpustakaan. Perpustakaan sebagai jantung pendidikan tinggi yang berperan sebagai penyedia informasi yang efektif, efisien dan dan menjadikan pengguna yang berwawasan luas secara akademik berusaha meningkatkan pelayanan dengan meningkatkan kualitas koleksi dengan menambah koleksi terbaru pada perpustakaan sesuai dengan perkembangan zaman. Lembaga pendidikan tinggi harus memiliki perpustakaan yang berteknologi tingi dan memberikan layanan informasi sehingg dapat membantu para akademisi dalam berbagai bidang tertentu untuk meningkatkan kualitas pendidikan dan melaksanakan tugas dan kewajiban mereka sesuai dengan latar belakang masing-masing pengguna perpustakaan.

Perpustakaan IAIN Batusangkar adalah perpustakaan lembaga pendidikan tinggi yang memiliki \pm 8.000 mahasiswa, \pm 400 orang dosen dengan koleksi \pm 15.000 judul dengan berbagai macam bidang ilmu umum, social, agama, hukum, sesuai dengan semua bidang jurusan yang ada di IAIN Batusangkar. Jumlah koleksi dirasa belum mencukupi kebutuhan secara akademik. Kebutuhan akademik akan kebaharuan materi dan informasi melalui koleksi kepada seluruh pengguna baik mahasiswa, dosen dan karyawan yang ada di IAIN Batusangkar perlu dilakukan pengembangan dan permbaharuan informasi.

Pada kondisi saat ini pengembangan perpustakaan juga dilakukan tidak hanya untuk memenuhi kebutuhan pengguna dilingkungan IAIN Batusangkar secara khusus, namun meningkatkan wawasan pengetahuan masyarakat sebagai bentuk pemberdayaan masyarakat melalui perpustakaan juga menjadi target pengguna perpusakaan IAIN Batusangkar seperti mayarakakat akademik luar kampus, masyarakat lingkungan, siswa dan seluruh pengguna yang berada disekitar perpustakaan IAIN Batusangkar. Berdasarkan hal ini kebutuhan masyarakat.

Kebutuhan pengguna yang berbagai macam latar belakang dengan menganalisis kebutuhan koleksi yang digunakan agar sesuai yang dibutuhkan pemustaka secara tepat dan efisien. Perpustakaan IAIN Batusangkar perlu memproses dalam bentuk pengumpulan dan pengolahan informasi secara efektif sesuai dengan kebutuhan pemustaka. Pengembangan koleksi perpustakaan membutuhkan analisis yang tepat dan efisien demi ketercapaian pengelolaan dan pelayanan perpustakaan. Berdasarkan penjelasan di atas, penelitian ini adalah menggunakan pertanyaan sebagai berikut: 1). Bagaimana bentuk analisis kebutuhan informasi koleksi pemustaka pada perpustakaan IAIN Batusangkar saat ini? 2). Apa saja hambatan yang dihadapi? Tujuan dari penelitian: mengidentifikasi bentuk pelaksanaan kegiatan analisis kebutuhan koleksi pengguna dalam rangka pengembangan perpustakaan IAIN Batusangkar, menganalisis hambatan yang dihadapi dalam memenuhi 
kebutuhan sesuai keinginan pengguna, memberikan keluaran untuk kegiatan analisis kebutuhan pengguna secara menyeluruh dan komprehensif.

\section{B. METODE}

Penelitian ini merupakan penelitian studi kasus. Mulyana (2008:26) mengatakan, Penelitian studi kasus merupakan deskripsi dan penjelasan yang menyeluruh bagi berbagai pihak baik individu, instansi dalam kelompok maupun organisasi (komunitas), program data atau situasi sosial. Penelitian studi kasus berusaha menganalisis data sebanyak mungkin terkait dengan subjek yang diteliti. Metode penelitian yang digunakan dalam bentuk wawancara, observasi, pengawatan lapangan, survei data, dokumen dan informasi lingkungan untuk menggambarkan suatu kasus secara lebih rinci dan mendalam.

Kasus Penelitian ini berfokus pada menganalisis kebutuhan layanan koleksi pengguna dalam pengembangan koleksi perpustakaan IAIN Batusangkar. Kasus digambarkan melalui hubungan antara orang yang berkontribusi dalam pelaksanaan kegiatan analisis tersebut. Kasus dalam penelitian ini berupaya menggali lebih dalam terkait permasalahan dengan tujuan untuk memperoleh informasi yang lebih menyeluruh dan valid. Pustakawan perpustakaan IAIN Batusangkar dijadikan sebagai subjek penelitian sedangkan objek penelitian adalah pengembangan koleksi Perpustakaan. Setiap kegiatan penelitian, objek atau target yang diperlukan dan objek atau target umumnya dalam jumlah besar. Survei penelitian, tidak semua individu dalam populasi objek harus diperiksa. Sampel penelitian adalah beberapa informan yang memenuhi kriteria sebagai representasi objek penelitian. Masalah penting dalam pengumpulan data yang harus dipertimbangkan adalah "bagaimana bisa dipastikan atau percaya bahwa sampel yang ditentukan adalah representatif" (Australian Library and Information Association, 2014) .

Informan wawancara ini adalah orang-orang yang berwenang dalam mengembangkan koleksi atau dapat disebut sebagai informan kunci. Informan kunci adalah seseorang atau lebih yang diyakini dapat memberikan informasi yang berguna untuk studi. Informasi utama ini berasal dari pihak berwenang dalam pengembangan koleksi, yaitu pustakawan yang terlibat dalam tim pengembangan koleksi, pustakawan yang bertanggung jawab atas pengembangan koleksi, dan kepala perpustakaan. Data mentah yang telah dikumpulkan kemudian memasuki fase analisis. Sebelum dianalisis secara menyeluruh, data dalam bentuk wawancara dibuat transkrip (salinan dalam bentuk tertulis) yang disampaikan (Ayoub, Amin, Ashraf Wani, \& Wani, 2018). Lebih lanjut data diklasifikasikan berdasarkan tujuan penelitian yang kemudian, data dianalisis dengan membandingkan pola yang diharapkan penulis berdasarkan literatur dengan pola yang ditemukan dalam wawancara dan data observasi

\section{TINJAUAN LITERATUR}

\section{Pengembangan Koleksi Buku Perpustakaan}

Koleksi perpustakaan sebagai faktor utama dalam menunjang potensi akademik keberadaan perpustakaan. Koleksi berarti jumlah buku atau bahan pustaka lainnya dalam bidang atau jenis yang dikumpulkan suatu lembaga organisasi instansi tertentu (G. Edward 
Evans, 2005). Pengembangan layanan koleksi merupakan keiatan yang menjelaskan informasi pada perpustakaan tersampaikan kepada pengguna perpustakaan secara tepat, cepat dan efektif sesuai dengan kebutuhan baik bagi pemustaka dari dalam maupun dari luar perpusakaan. Pengembangan koleksi diusahakan sesuai dengan jumlah pengguna pada perpustakaan IAIN Batusangkar dimana pengguna tidak hanya berasal dari civitas akademik namun berasal dari luar civitas akademik fakultas. (Johnson Peggy, 2004) menjelaskan bahwa pengembangan koleksi perpustakaan di akhir tahun 1960-an merupakan istilah yang mempunyai konotasi yang lebih luas dalam menggantikan seleksi menjadi istilah secara keseluruhan dalam proses pengembangan koleksi yang tidak terkecuali dengan mempertimbangkan pendapat dari pengguna.

Kebijakan pengembangan koleksi mulai memperhatikan kebutuhan dan keinginan pengguna informasi agar leibih potensial dalam penggunaan layanan koleksi agar informasi yang diperoleh lebih tepat sasaran pada pengguna yang membutuhkan. Pengembangan koleksi adalah suatu istilah yang digunakan secara luas di dunia perpustakaan untuk menyatakan bahan pustaka apa saja yang harus diadakan di perpustakaan. Kegiatan pemilihan buku artinya memilih buku untuk perpustakaan. Pemilihan buku berarti juga proses menolak buku tertentu untuk perpustakaan yang merupakan kegiatan dalam manajemen koleksi menyangkut organisasi dan tugas dari tanggungjawab secara praktikal (Semertzaki, 2011). Collection development sebagai suatu proses untuk mengetahui peta kekuatan dan kekurangan atau kelemahan koleksi perpustakaan, sehingga dapat merencanakan perbaikan peta kelemahan tadi dan mempertahankan kekuatan koleksi. Dia menambahkan bahwa, "collection developmet is a 'written statement' of that plan, providing details for guidance of the library staff",

Pengembangan koleksi merupakan suatu proses universal untuk perpustakaan karena setiap perpustakaan akan membangun koleksi yang kuat demi kepentingan pengguna perpustakaan. Kegiatan membangun koleksi perpustakaan tersebut dikenal dengan istilah pengembangan koleksi.

Dari definisi di atas dapat disimpulkan bahwa pengembangan koleksi merupakan suatu proses kegiatan yang mencakup sejumlah kegiatan yang berhubungan dengan pengembangan koleksi perpustakaan, termasuk menetapkan dan koordinasi terhadap kebijakan seleksi, penilaian terhadap kebutuhan pengguna dan pengguna potensial, kajian penggunaan koleksi, evaluasi koleksi, identifikasi kebutuhan koleksi, seleksi bahan pustaka, perencanaan untuk bekerjasama, pemeliharaan koleksi, dan penyiangan (ahmad: 2012). Pengembangan koleksi haruslah memperhatikan faktor-faktor antara lain: 1) Kebutuhan pengguna perpustakaan (user); 2) Kebijakan Pengembangan Koleksi (Collection Development policy); 3) Seleksi kebutuhan sesuai anggaran (Selection); 4) Akuisusu/ pengadaan dimana memperoleh bahan koleksi baik melalui pembelian, hadiah maupun hibah; 5) Penyimpanan (Deselection); 6) Evaluasi pengadaan sesuai dengan tujuan baik ekternal maupun internal (G. Edward Evans, 2005). 


\section{Mengidentifikasi Kebutuhan Pengguna Koleksi Perpustakaan}

Identifikasi kebutuhan pengguna/ pemustaka merupaan suatu keperluan dari seorang pemustaka dalam menemukan dan mencari serta menelusuri infomasi yang sesuai kebutuhannya dengan menggunakan berbagai fasilitas telusur kembali dengan memanfaarkan layanan manual maupun berbasis IT. (G. Edward Evans, 2005) Koleksi yang baik hanya berasal dari pemilihan bahan perpustakaan yang baik pula. Untuk itu diperlukan kebijakan yang memandu pengembangan koleksi. Dengan kebijakan pengembangan koleksi, yang secara resmi disahkan oleh pimpinan lembaga ybs, perpustakaan memiliki pegangan untuk mengembangkan koleksinya. Data kebutuhan pemustaka yang terkumpul mengenai layanan koleksi untuk kebutuhan pemustaka.

Beberapa fasilitas yang diberikan perpustakaan untuk memenuhi kebutuhan pemustaka diantaranya: 1) Menyediakan Koleksi; 2) Menyediakan catalog; 3) Menyediakan bantuan layanan pustakawan; 4) pelayanan sirkulasi peminjaman dan pengembalian (G. Edward Evans, 2005).

(G. Edward Evans, 2005) Penyiangan koleksi adalah suatu proses seleksi dan penarikan koleksi dari perpustakaan: karena suatu keperluan tertentu, karena tidak bermanfaat lagi bagi pengguna perpustakaan yang bersangkutan, atau terjadi perubahan subjek untuk bahan pustaka yang akan dijadikan koleksi, atau bahkan karena sangat dibutuhkan oleh perpustakaan lain. Kewenangan merumuskan kebijakan pengembangan koleksi dipercayakan kepada: 1. Pustakawan dan pengelola perpustakaan 2. Para Peneliti, Dosen, Mahasiswa yang akan menggunakan koleksi sebagai sumber informasi. Pendekatan yang dilakukan dalam pengambil keputusan dengan menyediakan data klasifikasi informasi kebutuhan pengguna yang dihimpun setiap hari dengan mengadakan wawancara secara langsung pada saat pelayanan sirkuasi ataupun dengan menerima kebutuhan koleksi melalui kotak saran yang diberikan pengguna.

\section{HASIL DAN PEMBAHASAN}

\section{Pengembangan Koleksi di Perpustakaan IAIN Batusangkar}

Eksistensi suatu perpustakaan tergantung dari koleksi yang dimiliki. Tujuan utama dari pemustaka datang ke perpustakaan adalah untuk memperoleh informasi yang dibutuhkan. Oleh karena itu Koleksi bahan perpustakaan harus dapat mengakomodir kebutuhan pengguna dan selaras visi misi perpustakaan. Perpustakaan yang tidak dapat memenuhi kebutuhan penggunanya tentu akan kehilangan eksistensinya. Diperlukan suatu metode seleksi bahan pustaka sedemikian rupa sehingga mampu mengidentifikasi koleksi yang dibutuhkan. Secara umum, kegiatan seleksi adalah proses mengidentifikasi kebutuhan. Pada konteks perpustakaan perguruan tinggi, kegiatan seleksi terhadap koleksi pustaka harus sejalan dengan tujuan perpustakaan itu sendiri. Seleksi pengadaan buku dilakukan permintaan data usulan yang berasal dari siswa pengguna, dosen-dosen setiap jurusan yang ada di IAIN Batusangkar serta menyediakan form pengajuan usulan secara individu masing-masing kepada perpustakaan baik online maupun ofline. 
Strategi pengembangan layanan koleksi buku yang dilakukan Perpustakaan IAIN Batusangkar berisi beberapa unsur pengembangan koleksi seperti yang dijelaskan oleh Evans (2005) berdasarkan tugas utama perpustakaan adalah membangun dan mengembangkan koleksi yang kuat demi kepentingan pengguna melalui beberapa tahapan pengembangan koleksi.

\section{Kegiatan Analisis Kebutuhan Pengguna}

Perpustakaan Pusat IAIN Batusangkar menyediakan ebook yang berlangganan dari berbagai situs yang telah berlangganan sejak 2014 hingga sekarang. Selain itu Perpustakaan Pusat IAIN Batusangkar berlangganan jurnal online dari Proquest, Ebsco, Gale, Emerald, Springer, Oxford dan Cambridge. Lembaga Ilmu Pengetahuan Indonesia (LIPI) merekomendasikan agar referensi utama dalam penulisan jurnal ilmiah setidaknya 80\% dari jurnal terakreditasi. Direktorat Jenderal Pendidikan Tinggi merekomendasikan bahwa jumlah referensi primer di atas $80 \%$ dengan harapan bahwa semakin banyak perpustakaan primer yang dirujuk, semakin baik kualitas penulisan. Oleh karena itu, Perpustakaan Pusat IAIN Batusangkar telah menyediakan ini untuk digunakan seluas mungkin untuk komunitas akademik.

\section{Budaya Membaca}

Pergeseran budaya tersebut menyebabkan Perpustakaan Pusat IAIN Batusangkar mengubah fungsinya dari tidak hanya sebagai tempat untuk meminjam buku dan kemudian membacanya, tetapi lebih dari itu, Perpustakaan Pusat IAIN Batusangkar sebagai tempat untuk mendiskusikan, menyelesaikan tugas-tugas perguruan tinggi atau hanya sekedar mendinginkan, dapatkan sinyal wifi. Peran perpustakaan sebagai pembelajaran umum, tempat untuk melakukan kegiatan belajar dapat diwujudkan dengan menyediakan tempat dan fasilitas yang representatif untuk beberapa komputer yang dapat dimanfaatkan serta akses internet yang mudah melalui wifi.

\section{Epistemic Komunitas (Minang Corner)}

Pencapaian Perpustakaan Pusat IAIN Batusangkar pada tahun 2019 adalah peresmian Pojok Minang di Perpustakaan selama kelulusan XI yang terletak di sebelah koleksi publik dan hukum Islam di Perpustakaan Pusat IAIN Batusangkar. Minang Corner di Reader bukan hanya tempat nongkrong atau membaca koleksi yang berbau khas Minang, tetapi juga sebagai tempat membangun budaya dan hubungan sosial serta berbagi pengetahuan dan pengalaman. Seperti slogannya, "Alam Takambang Jadi Guru". Sudut baca Minang dirancang sebagai ruang publik terbuka, ruang belajar bersama, dan ruang untuk membangun kesadaran kreatif bersama yang terbuka bagi siapa saja yang ingin memperkuat literasi. Diharapkan dengan sudut Minang di perpustakaan dapat membentuk komunitas epistemik dari berbagai akademisi dengan latar belakang ilmiah yang beragam, berbaur dan melebur dalam diskusi santai. 


\section{Ruang Multimedia (Tempat Kreativitas)}

Perpustakaan Pusat IAIN Batusangkar memiliki ruang multimedia sebagai tempat untuk memberikan kebebasan kepada pengguna untuk memanfaatkan ruang multimedia sebagai ruang audio visual untuk pengembangan diri setiap pengguna sesuai dengan bidang keilmuan yang dimilikinya. Ruang ini bisa digunakan oleh semua pengguna. Ruang ini diharapkan dapat memberikan manfaat data dengan menyediakan ruang untuk kreativitas dan melahirkan ide-ide baru dari tempat-tempat baru.

Perpustakaan adalah satu-satunya tempat umum yang dikunjungi oleh komunitas akademik IAIN Batusangkar, terutama mahasiswa dan dosen. Seorang jurnalis dari Inggris, Holbrook Jackson mengatakan, "Perpustakaan Anda adalah potret Anda". Perpustakaan Pusat IAIN Batusangkar adalah cerminan dari IAIN Batusangkar. Terlepas dari fasilitas yang disediakan untuk mendukung implementasi "3 Tridharma" pendidikan tinggi melalui perpustakaan, seperti itulah citra dan kualitas universitas. Singkatnya, untuk melihat bagaimana kualitas perguruan tinggi, lihatlah perpustakaan. Karena kualitas pendidikan tinggi adalah linier dengan fasilitas dan pemberdayaan sumber daya yang dimiliki perpustakaan.

Berikut ini adalah berbagai fasilitas di perpustakaan IAIN Batusangkar saat ini:
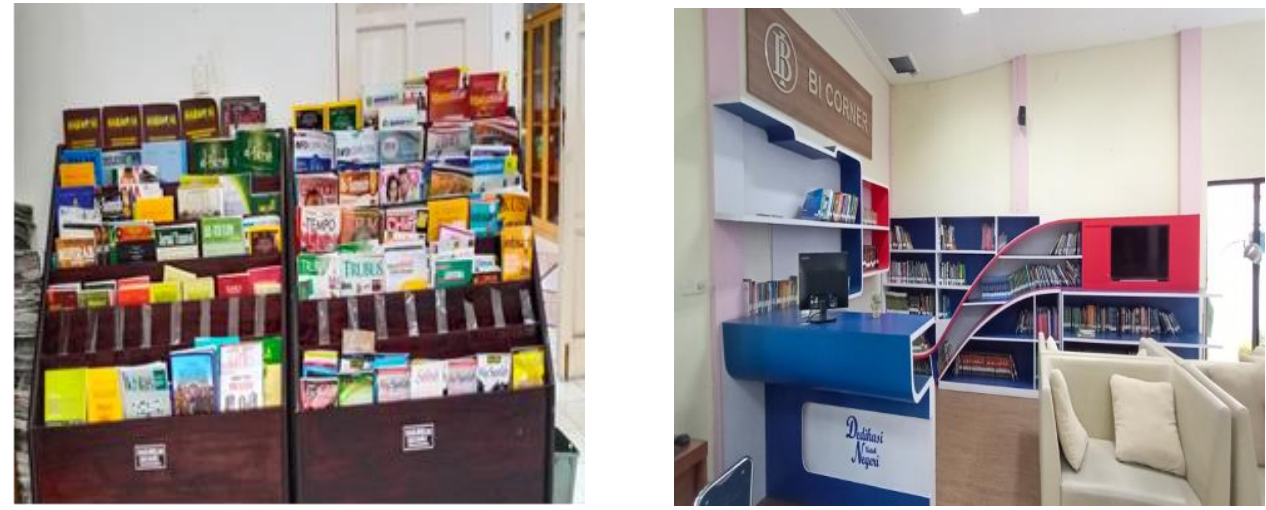

Gambar. 1 Berbagai Fasilitas di perpustakaan IAIN Batusangkar

\section{Implementasi Pengembangan Layanan Koleksi Buku pada Perpustakaan IAIN Batusangkar}

Pengembangan koleksi ditafsirkan oleh pustakawan Perpustakaan IAIN Batusangkar sebagai tambahan kepemilikan bahan pustaka baik dalam bentuk soft koleksi maupun hard koleksi (buku). penambahan koleksi dilakukan dengan pembelian melalui penggandaan yang dianggarkan dalam dana operasional perpustakaan setiap tahunnya. Pengadaan koleksi dilakukan berdasarkan pada permintaan dari pengguna perpustakaan, terutama permintaan dari dosen di setiap unit dan fakultas IAIN Batusangkar dengan cara memberikan formulir kebutuhan koleksi dari perpustakaan.

Strategi pengembangan koleksi yang dilakukan Perpustakaan IAIN Batusangkar berisi beberapa elemen pengembangan koleksi seperti dijelaskan oleh (G. Edward Evans, 2005), yaitu melakukan identifikasi analisis kebutuhan koleksi pengguna, pemilihan bahan 
pustaka, pengadaan melalui hadiah, berbagi sumber daya dan simpanan, dan penyiangan koleksi dan evaluasi. Beberapa elemen telah diatur dalam peraturan tertulis seperti identifikasi kebutuhan pengguna dan pembelian yang diatur dalam SOP Pengadaan.

\section{Identifikasi Analisis Kebutuhan Pengguna}

Perpustakaan harus menyediakan koleksi yang sesuai dengan kebutuhan penggunanya. Pengadaan buku ini biasanya dilakukan dengan dua cara. Pertama adalah permintaan buku berdasarkan topik yang diajukan oleh pengguna. Misalnya, Dosen mengusulkan kepada pustakawan bahwa mereka membutuhkan buku tentang topik sesuai dengan bidang pendidikan mereka ataupun melalui pengisian form yang disediakan petugas perpustakaan pada web secara daring.

Kedua adalah permintaan pengguna yang dihimpun melalui catatan pustakawan atau informasi lisan dan tulisan dari berbagai pengguna yang datang keperpustakaan diantaranya dosen, karyawan, atau mahasiswa. Setiap pengguna ini membutuhkan buku atau informasi di perpustakaan. Jika perpustakaan tidak memilikinya, pengguna dapat meminta pustakawan untuk mencatat judul buku yang mereka butuhkan dan mengklasifikasi kebutuhan dalam daftar table kebutuhan koleksi yang harus di adakan dalam koleksi berikutnya.

Catatan pengguna ini juga digunakan sebagai usulan ke perpustakaan untuk dipertimbangkan dalam pengadaan. Jika dilihat implementasi pengadaan koleksi berdasarkan permintaan pengguna yang diterapkan oleh Perpustakaan IAIN Batusangkar melibatkan seluruh civitas akademik sebagai pengguna tetap perpustakaan. Analisis usulan pengguna dipandang sebagai informasi dinamis yang selalu dihimpun petugas untuk pengadaan koleksi perpustakaan. Usulan secara tertulis maupun langsung secara lisan kepada pustakawan dapat dijadikan sebagai bahan arsip dinamis yang harus dipenuhi dan masuk ke dalam daftar anggaran tahun berikutnya (G. Edward Evans, 2005).

Evaluasi hasil usulan kebutuhan pengguna kemudian dapat dianalisis melalui observasi, wawancara, atau identifikasi saluran informasi yang biasa digunakan oleh pengguna, dalam hal ini, pengguna utama Perpustakaan IAIN Batusangkar, yaitu Dosen, staf pendidikan dan mahasiswa. Juga dimungkinkan bagi pustakawan untuk melakukan survei atau wawancara dengan pengguna lain yang sering mencari informasi di perpustakaan IAIN Batusangkar seperti pelajar, peneliti, atau praktisi. Informasi apa yang mereka harapkan dari perpustakaan IAIN Batusangkar sehingga nantinya akan menjadi patokan bagi perpustakaan untuk memberikan layanan yang optimal dalam bidang koleksi yang dimiliki.

Mengelompookan kebutuhan koleksi buku sesuai dengan permintaan dari pengguna dipandang sebagai tindakan yang intens Kebutuhan seperti yang dijelaskan oleh pengguna individu hanya menggambarkan sebagian dari kebutuhan mereka. Pustakawan dapat menggunakan standar SOP pengumpulan untuk pendidikan, dan informasi bagi civitas akademik dengan mempertimbangkan unit kerja IAIN Batusangkar dan kebutuhan informasi mereka, serta perkembangan (kemajuan) terbaru dalam pendidikan. 
Pemilihan koleksi buku oleh perpustakaan IAIN Batusangkar dapat dilihat dari daftar usulan buku oleh pengguna. Buku yang diusulkan dari pengguna kemudian dicari melalui katalog penerbit di internet. Setelah didapat pilihlah buku yang sebelumnya telah dibuat daftar oleh pustakawan. Memilih di sini adalah dosen yang menjadi target utama layanan perpustakaan IAIN Batusangkar. Buku-buku yang dipilih sebelumnya telah dibuat daftar yang disusun dari katalog penerbit. Katalog penerbit ini diperoleh dari browsing di internet dan katalog cetak diperoleh dari penerbit secara langsung. Katalog cetak ini disediakan atas permintaan perpustakaan atau penerbit yang datang ke perpustakaan dan menawarkan koleksi mereka.

Dalam kegiatan ini, pustakawan juga menyediakan formulir untuk mengisi kebutuhan pengumpulan online atau online. Ini adalah salah satu strategi untuk mempercepat mendapatkan informasi dari pengguna tanpa kecuali. (Yuliani, 2018b) mengatakan salah satu cara untuk meningkatkan layanan dan kepuasan pengguna adalah dengan memberikan informasi yang cepat dan akurat. Menangkap kebutuhan pengguna melalui formulir online dari situs web akan lebih cepat menargetkan semua jenis koleksi yang dibutuhkan oleh pengguna sehingga informasi dapat disampaikan dengan benar.

Setelah buku dipilih dan diperiksa atau diperiksa oleh pustakawan. Daftar buku yang dipilih dikembalikan ke perpustakaan untuk dianalisis lagi sehubungan dengan database jika ternyata buku tersebut sudah dimiliki dan terkait dengan harga untuk dana pendamping. Jika sudah dianalisis hasil undangan ini kemudian dibuat daftar lagi, diajukan ke vendor baru kemudian dilakukan pembelian. Dalam SOP pengadaan dijelaskan bahwa pustakawan IAIN Batusangkar menyusun daftar buku dari katalog penerbit dan kemudian mengetik ulang dan membagikannya kepada dosen di lembaga pendidikan. Daftar buku yang telah didistribusikan kepada para dosen ini nantinya akan dipilih oleh pustakawan dengan melewati judul buku yang diperlukan. Inilah hasil persimpangan yang kemudian menjadi referensi utama dalam pengadaan.

Alat pemilihan koleksi di perpustakaan IAIN Batusangkar mengandalkan katalog dan katalog buku online dan cetak yang diperoleh dari internet atau situs web terkait. Metode pemilihan biasanya langsung terbuka ke situs web penerbit dan mencari buku-buku mengikuti persyaratan pengadaan tahunan perpustakaan IAIN Batusangkar. Katalog buku dalam bentuk cetak yang ditawarkan atau diminta kepada penerbit atau vendor. Selain itu seleksi juga memperhatikan bahasa, format koleksi, dan koleksi fisik. Untuk bahasa, perpustakaan IAIN Batusangkar tidak memiliki kriteria khusus mengenai bahasa koleksi yang akan diadakan. Sebagian besar koleksi yang dimiliki adalah koleksi dalam bahasa Indonesia dan Arab berdasarkan kebutuhan pengguna.

Pada pertimbangan pengadaan berdasarkan format koleksi, perpustakaan IAIN Batusangkar masih berkonsentrasi pada pengadaan koleksi cetak. Alasannya adalah bahwa masih banyak pengguna yang mencari koleksi cetak, terutama siswa dengan mata pelajaran pendidikan bahasa asing dan lebih suka koleksi cetak. Bahkan jika ada format digital, format cetak juga masih diminta. Menurut pernyataan pustakawan bahwa Perpustakaan IAIN Batusangkar telah berlangganan jurnal ilmiah dalam bentuk digital. Namun ternyata penggunanya sangat sedikit sementara biaya yang dikeluarkan cukup besar, Perpustakaan 
IAIN Batusangkar terus berupaya meningkatkan masyarakat melalui media sosial untuk memberikan informasi terkait ketersediaan jurnal online dan cetak. Saat ini diperlukan pertimbangan bagi Perpustakaan IAIN Batusangkar untuk memiliki koleksi dalam bentuk digital. Menurut (G. Edward Evans, 2005) menyatakan, pengembangan koleksi harus mempertimbangkan semua format informasi untuk dimasukkan dalam koleksi. mengingat Perpustakaan IAIN Batusangkar adalah perpustakaan pusat yang akan memiliki unit perpustakaan lain di berbagai fakultas di IAIN Batusangkar, akan sangat bermanfaat jika mereka memiliki koleksi digital yang dapat diakses dari jarak jauh.

Berdasarkan (G. Edward Evans, 2005), mempertimbangkan kebutuhan berlangganan koleksi dalam bentuk digital harus dipertimbangkan dengan analisis yang matang. Memiliki berbagai format koleksi buku baik online maupun ofline dapat diajukan melalui formulir kebutuhan pengguna sehingga mereka harus memiliki komitmen keuangan dalam manajemen perpustakaan. Pengembangan e-serial / e-digital harus diikuti oleh perkembangan di bidang teknologi dan kemampuan perpustakaan sendiri untuk menciptakan perpustakaan berbasis digital. Perpustakaan (pustakawan) harus dapat memilah jurnal yang diperlukan dengan hati-hati. Merancang perpustakaan berbasis elektronik dengan mengembangkan konsep perpustakaan elektronik membutuhkan perangkat elektronik atau melakukan kegiatan dengan jaringan internet tidak terkecuali dengan mengumpulkan informasi tentang kebutuhan pengguna secara online. ini adalah salah satu tantangan masa depan yang harus diselesaikan oleh IAIN Batusangkar itu sendiri terkait dengan perangkat untuk mewujudkan konsep perpustakaan "e-library" oleh (Yuliani, 2018a).

\section{Menganalisis Kendala yang dihadapi Perpustakaan IAIN Batusangkar}

Kendala juga diperoleh dari analisis kebutuhan praktik pengguna Perpustakaan IAIN Batusangkar di mana perpustakaan IAIN Batusangkar sangat tergantung pada usulan langsung judul buku yang diajukan oleh siswa, pengguna, dosen dan semua komunitas akademik atau pengguna lain seperti masyarakat dan praktisi. Menurut data yang diambil dari wawancara dengan salah satu informan, justru usulan buku seperti inilah yang sangat diharapkan. Keterlibatan pengguna dalam pengadaan koleksi buku di Perpustakaan IAIN Batusangkar dilakukan dengan memesan buku sesuai kebutuhan mereka inginkan untuk dapat digunakan dimasa mendatang. Keadaan seperti ini terkadang tidak berjalan maksmilal tetapi ini adalah paradoks karena urutan untuk buku yang diusulkan tidak selalu tersedia setiap saat dan kadang-kadang pustakawan bingung menentukan buku yang akan dipegang, sehingga perpustakaan sendiri yang memutuskan buku apa yang akan dipegang.

Ada melakukan ini dengan menawarkan langsung kepada dosen dan mahasiswa daftar buku yang telah diperoleh dari katalog penerbit. dilihat dari berbagai segi permasaahan ada beberapa yang terdekti sebagai kendala yang dihadapi dalam pengadaan dan pengembangan koleksi buku yang ada di perpustakaan IAIN Batusangkar diantaranya: 1) Aspek kelembagaan dimana tidak adanya kesatuan struktur organisasi perpustakaan yang mengatur khusus pengelolaan permintaan koleksi buku sesuai kebutuhan pemustaka; 2) Aspek pendanaan yang belum stabil dimana kebutuhan dana pengadan telah teralokasi 
dan mengalami peningkatan yang tidak signifikan dari tahun-ketahun; 3) Aspek Sumber Daya Manusia dimana pengelola perpustakaan tidak seimbang dengan koleksi yang dikelola; 4) pertimbangan gedung dan ruang perpustakaa yang belum valid dan sesuai dengan perkembangan pengunjung.

\section{E. PENUTUP}

Pustakawan IAIN Batusangkar meyakini proses pengembangan koleksi sesuai dengan kebutuhan pengguna bias melalui beberapa cara dan strategi yang dilalui. Kegiatan ini dilakukan baik melalui permintaan pemenuhan koleksi langsung maupun tidak langsung dengan mengisi form online dan ofline. Kegiatan pemenuhan kebutuhan pengguna sejauh ini sudah dilakukan berdasarkan SOP yang telah ada namun hasilnya belum menjelaskan secara keseluruhan kebutuhan yang diinginkan pemustaka. Analisis dan cara pengolahan data informasi yang mendalam belum sepenuhnya dilakukan mengakibatkan terkadang koleksi yang di beli menjadi sama dalam waktu yang berulangulang. Analisis meskipun telah mengunpulkan dari beragam informasi namun belum memenuhi secara keseluruhan layanan koleksi yang diberikan oleh perpustakaan kepada pemustaka secara komprehensif.

Saran yang dapat diberikan dalam penelitian ini adalah Perpustakaan Pustaka IAIN Batusangkar sebagai perpustakaan Perguruan tinggi yang dijadikan jantung pendidikan di IAIN Batusangkar dapat lebih mendalam untuk menganalisis kebutuhan pengguna dan mengelompokkan kebutuhan baik itu kebutuhan khusu maupun kebutuhan umum bagi civitas akademik guna meningkatkan mutu dan literasi informasi civitas akademik dan masyarakat lingkungan sekitar perpustakaan.

\section{DAFTAR PUSTAKA}

Australian Library and Information Association. (2014). The Library and Information Sector: Core Knowledge, Skills and Attributes. (December), 1-6.

Ayoub, A., Amin, S., Ashraf Wani, Z., \& Wani, Z. A. (2018). International Coalition of Library Consortia (ICOLC): Exploring the Diversity and Strength of Participating Library Consortia. Library Philosophy and Practice, 1(Exploring the Diversity and Strength of Participating Library Consortia), 18. Retrieved from http://digitalcommons.unl.edu/libphilprac/2115

G. Edward Evans, M. Z. S. (2005). Library and community (5th Editio; LIbrary of Congress Catalog Card umber 200501098, ed.). United States: Library Unlimited, 88 Post Road Westport, CT 06881 A Member of the Greenwood Publishing Group, Inc.

Johnson Peggy. (2004). Fundamentals of Collection Development and Management. In A. L. Association (Ed.), American National Standard for Information Sciences (ALA Editio). https://doi.org/10.1017/CBO9781107415324.004

Mount, E., and Massoud, R. 1999. Special Libraries and Information Centers: An Introductory Text. Washington DC, USA: Special Libraries Association.

Mulyana, D. 2008. Metodologi Penelitian Kualitatif: Paradigma baru ilmu komunikasi dan ilmu social lainnya. Bandung: Remaja Rosdakarya.

Pickard, A. J. 2007. Research methods in information. London: Facet Publishing 
Semertzaki, E. (2011). Special libraries as knowledge management centres. Special Libraries As Knowledge Management Centres, 1-314. https://doi.org/10.1533/9781780632667

Yuliani, T. (2018a). Pengembangan E-Library Dalam Meningkatkan Pelayanan Di Perpustakaan Iain Batusangkar. Alfuad: Jurnal Sosial Keagamaan, 1(1), 16. https://doi.org/10.31958/alfuad.v1i1.1154

Yuliani, T. (2018b). The influence of the quality of service to customer loyalty. Al-Fuad 2018, 2(1), 35-47. https://doi.org/10.1007/s13398-014-0173-7.2 